\title{
Comparative study on the contamination and decontamination of Japanese oyster Crassostrea gigas and blue mussel Mytilus edulis by oxytetracycline and oxolinic acid
}

\author{
Hervé Pouliquen ${ }^{1, *}$, Hervé Le Bris ${ }^{2}$, Vincent Buchet ${ }^{3}$, Louis Pinault ${ }^{1}$ \\ ${ }^{1}$ Laboratoire de pharmacie et toxicologie, ${ }^{2}$ Laboratoire d'aquaculture et pathologie aquacole, Ecole Nationale Vétérinaire, \\ CP 3013, F-44087 Nantes Cedex 03, France \\ ${ }^{3}$ IFREMER, Station Aqualive, Le Terrain Neuf, BP 59, F-85330 Noirmoutier En L'Ile, France
}

\begin{abstract}
Marine fish farms use many antibacterial agents to prevent or fight bacterial diseases. The major part of the orally supplied drugs reach the environment, either directly due to excessive feeding and reduced appetite of the cultured fish, or indirectly after passing through the fish. Some of the drugs entering the environment may be taken up by bivalves. Comparative contamination and decontamination of Japanese oyster Crassostrea gigas and blue mussel Mytilus edulis were studied when these bivalves were kept during $10 \mathrm{~d}$ in seawater containing oxytetracycline (OTC) or oxolinic acid (OA) at concentrations of 0.15 and $1.50 \mathrm{mg} \mathrm{l}^{-1}$ After the $10 \mathrm{~d}$ exposure at the seawater concentrations of 0.15 and $1.50 \mathrm{mg} \mathrm{l}^{-1}$, OTC and OA concentrations in bivalve tissues were respectively 0.09 to 0.16 and 0.70 to $1.40 \mathrm{mg} \mathrm{kg}^{-1}$ OTC, which is in a large part bound to ions and organic molecules in seawater, was less absorbed by bivalves than $O A$ and therefore contaminated their tissues less than did $O A$. However, OTC, whose binding to mineral and organic compounds of the bivalve tissues is stronger than OA, was eliminated more slowly from the bivalve tissues than $O A$. Differences of contamination and decontamination of the bivalve species may be related to some chemical properties of the antibacterial agents and to some anatomical and physiological specificities of the bivalve. The biotransformations of the antibacterials agents by the bivalves did not seem to play a prominent part in the contamination and decontamination of the bivalve tissues.
\end{abstract}

KEY WORDS: Mussel · Oxolinic acid - Oxytetracycline - Oyster

\section{INTRODUCTION}

In marine fish farming, the semi-intensive or intensive rearing conditions lead to an increase in the occurence of infectious diseases. Since effective vaccines are available for only a limited range of pathogens, chemotherapy is considered to be the most effective weapon against bacterial diseases. Fish suffering from bacterial infections are usually treated orally using food pellets containing the desired antibacterial agent. Among the various antibacterial

\footnotetext{
•E-mail: Jphartox@vet-nantes.fr
}

agents used in fish treatments, oxytetracycline (OTC) and oxolinic acid (OA) are the most commonly prescribed because of their wide antibacterial spectra, their potency and their low cost.

Due to the reduced feeding of fish suffering from bacterial diseases, over-feeding may occur and excess food pellets may thus enter the environment. Furthermore, the low absorption of OTC and OA through the intestinal tract of fish (Cravedi et al. 1987) allows the drugs to enter the environment via faeces in an unchanged and active form. On the one hand, fragments of the drug-containing food pellets or faeces may be taken up by filter-feeders such as bivalves. On the other hand, drugs may also be released from pel- 
lets or faeces in a dissolved form which may be absorbed by other fauna directly from the water. Consequently, the release of OTC and OA from marine fish farms may be considered as a threat to neighbouring bivalve cultures.

Literature about contamination of bivalves by antibacterial agents is rare and contradictory. On the one hand, 2 experimental studies (Tibbs et al. 1989, Peterson et al. 1993) show the absence of contamination of bivalves placed in seawater containing OTC or tetracycline. On the other hand, some studies attest that fish antibacterial treatment can lead to a contamination of bivalves situated nearby (Hansen et al. 1992, Lunestad 1992, Samuelsen et al. 1992, 1993, Ervik et al. 1994). In a preliminary experiment, we also found that bivalves could be contaminated when exposed to simulated fish farm effluents containing OTC (Le Bris et al. 1995). Therefore, it is important to investigate contamination of wild or cultivated bivalves by OTC and OA. The aim of this experimental study was to compare the contamination and decontamination of Japanese oyster Crassostrea gigas and blue mussel Mytilus edulis by OTC and $O A$.

\section{MATERIAL AND METHODS}

Experimental conditions and apparatus. The experiment was carried out at the IFREMER Laboratory (Noirmoutier, France) in 8 tanks of $2.4 \mathrm{~m}^{3}$ called $\mathrm{A} 1$, A2, B1, B2, C1, C2, D1 and D2 (Fig. 1). Each tank was filled with $2000 \mathrm{l}$ of seawater filtered through a $150 \mu \mathrm{m}$ porosity membrane. Temperature, $\mathrm{pH}$ and salinity of seawater were respectively $12.0 \pm 0.5^{\circ} \mathrm{C}, 8.0 \pm 0.2$ and $33.0 \pm 0.5 \%$ (mean \pm standard deviation, $\mathrm{n}=15$ ). Then, 36 individuals of each bivalve species, Japanese oyster Crassostrea gigas and blue mussel Mytilus edulis, were placed in each tank. The individual weight of the oysters was $75.2 \pm 3.3 \mathrm{~g}$ and that of the mussels $15.7 \pm$ $2.1 \mathrm{~g}$ (mean \pm standard deviation, $\mathrm{n}=100$ ). All the tanks were supplied with air in order to maintain the dissolved oxygen concentration in seawater up to saturation and covered with a black plastic cover.

After the bivalves had acclimatized, under running filtered seawater $\left(1.4 \backslash \mathrm{min}^{-1}\right)$, to the tank conditions for $5 \mathrm{~d}_{1}$ the seawater circulation system was shut off. Antibacterial agents in pure form (OTC hydrochloride or $\mathrm{OA}$ ) were dissolved in $5 \mathrm{l}$ of filtered seawater and added to the seawater in each of the 8 tanks to give test concentrations of 0.15 and $1.50 \mathrm{mg} \mathrm{l}^{-1}$. Previous field observations of fish antibacterial treatments (Pouliquen et al. 1993, Le Bris et al. 1995) were used to select these 2 test concentrations. OA concentrations in seawater were $0.15 \mathrm{mg} \mathrm{l}^{-1}$ in tanks A1 and A2 and $1.50 \mathrm{mg} \mathrm{l}^{-1}$ in tanks B1 and B2. OTC concentrations in

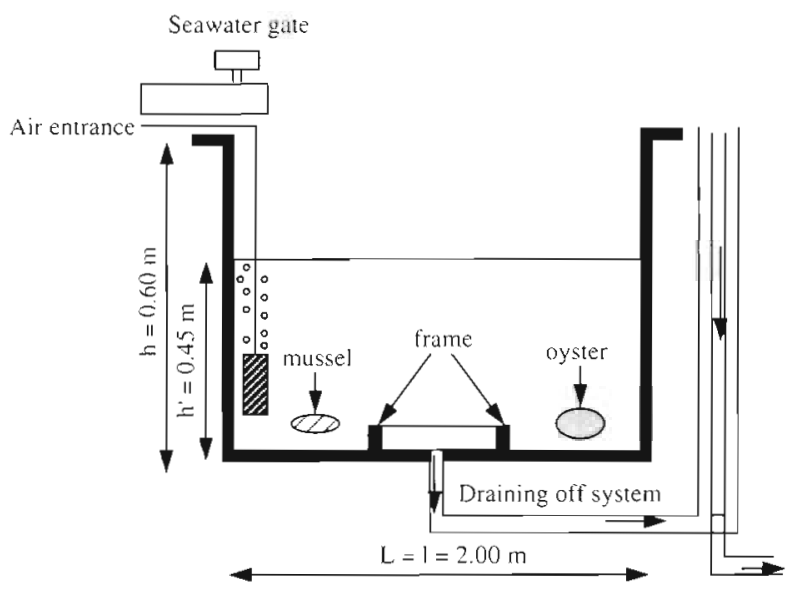

Fig. 1. Longitudinal section of a tank. L: length; l: width; h: height of the tank; h': height of the seawater level

seawater were $0.15 \mathrm{mg} \mathrm{\textrm {I } ^ { - 1 }}$ in tanks $\mathrm{C} 1$ and $\mathrm{C} 2$ and $1.50 \mathrm{mg} \mathrm{l}^{-1}$ in tanks D1 and D2. After $2 \mathrm{~d}$ exposure, the seawater was drained and the tanks were rinsed and again filled with 2000 l of filtcrod seawater to which the test antibacterial agent was added. All these manipulations were repeated on Days 2, 4, 6 and 8 of the exposure. On Day 10, the seawater was drained and tanks were rinced and again furnished with $2000 \mathrm{l}$ of filtered seawater. Then, the seawater circulation system was re-established with seawater flow of 1.41 $\min ^{-1}$ for $21 \mathrm{~d}$.

Sampling. Seawater and bivalves were sampled during the contamination ( $10 \mathrm{~d}$ long) and decontamination (21 d long) periods. Each group of 3 bivalves sampled was replaced by a marked group of the same weight in order to maintain the same volume of seawater filtered in the tank from the beginning to the end of the experiment. These marked bivalves were kept in the same experimental conditions in an additional drug-free tank until the time they were used to replace sampled bivalves in the 8 test tanks. They were marked in order to ensure they were not sampled during the rest of the experiment. Seawater samples were placed into polystyrene bottles and unmarked bivalve samples into polyethylene bags. All the samples were immediately stored in black polyethylene bags and maintained at $-20^{\circ} \mathrm{C}$ until the analyses were carried out.

Sample analysis. The quantitative determination of OTC and OA in seawater and bivalve tissues of the 3 individuals pooled together was performed according to the HPLC methods developed by Pouliquen et al. (1992, 1993, 1994).

Statistical and mathematical methods. A 1-way analysis of variance was used for comparing mean $O C T$ concentrations with mean OA concentrations and mean antibacterial agent concentrations in oyster tis- 
sues with those in mussel tissues during a same period after testing distribution normality and variances equality. Disappearance of OTC from bivalve tissues was well described by a monocompartmental kinetic model. Half-lives and mean residence times were calculated from the plot of the log of the drug concentrations ( $\mathrm{mg} \mathrm{kg}^{-1}$ ) versus time (d) using the RSTRIP ${ }^{(*)}$ software (Micromath Scientific Software, Salt Lake City, UT, USA].

\section{RESULTS}

During the contamination period, mean antibacterial agent concentration in seawater or bivalve tissues was not significantly different between replicate tanks ( $p$ > 0.05 ). During the decontamination period, mean OTC concentration in oyster or mussel tissues was not significantly different between replicate tanks C1 and C2
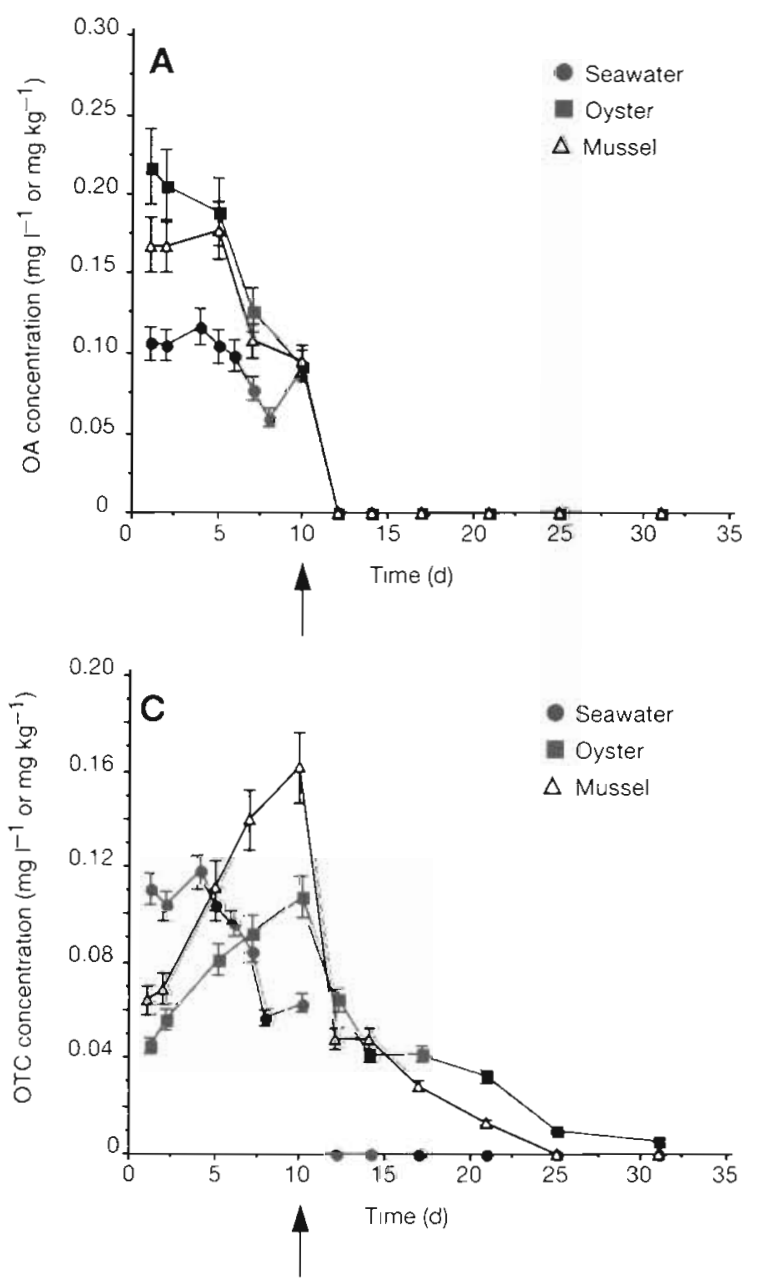

and D1 and D2 ( $p>0.05)$. During this same period, antibacterial agent concentrations in seawater and $O A$ concentrations in bivalve tissues were all below the detection limits of the analytical methods $10.01 \mathrm{mg} \mathrm{l}^{-1}$ or $\mathrm{mg} \mathrm{kg}^{-1}$ ). Mean antibacterial agent concentration in seawater and bivalve tissues was not different between the duplicate tanks maintained in the same experimental conditions. It was therefore possible to consider tanks A1 and A2, B1 and B2, C1 and C2, and $\mathrm{D} 1$ and $\mathrm{D} 2$ as same tanks called respectively tanks $A$, $B, C$ and $D$

\section{Contamination period}

Antibacterial agent concentrations in seawater were near their theoretical values, 0.15 or $1.50 \mathrm{mg} \mathrm{l}^{-1}$ (Fig. 2, Table 1). Mean OTC concentration was not significantly different from mean OA concentration ( $p>0.05)$.
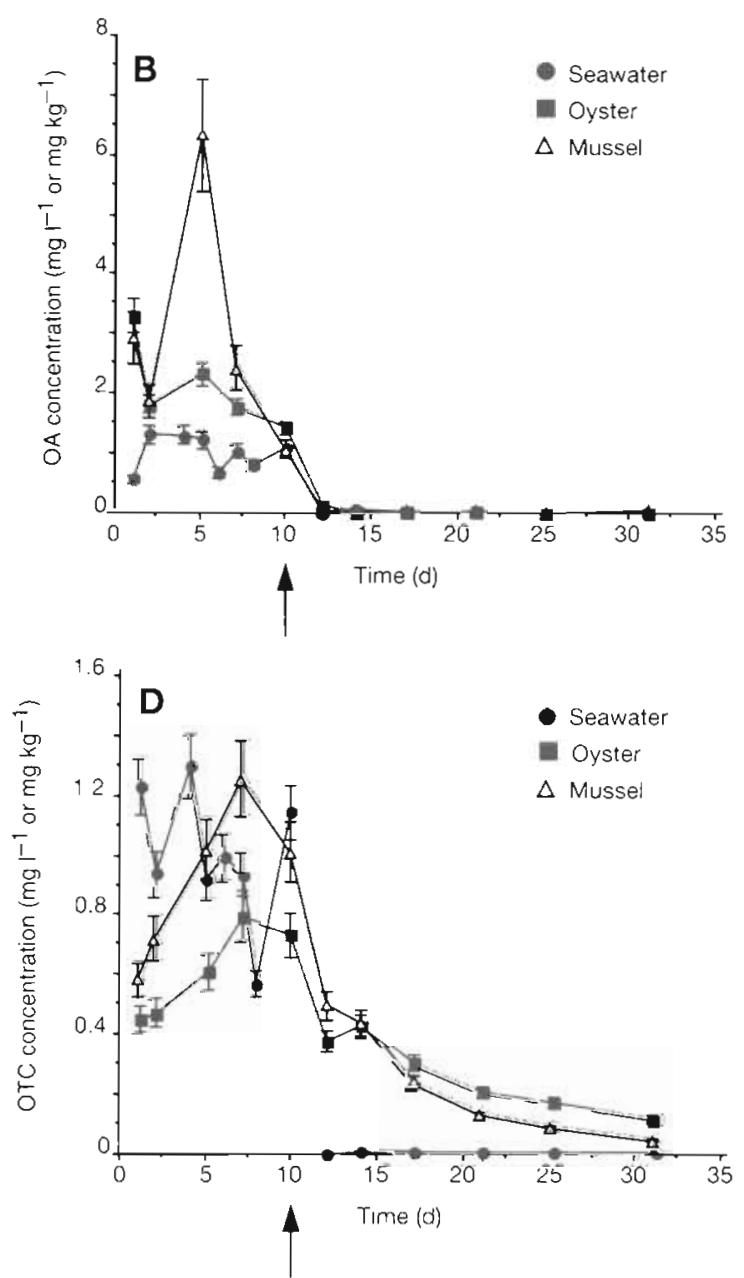

Fig. 2. Kinetics of oxolinic acid (OA) and oxytetracycline (OTC) in seawater, oyster and mussel tissues kept during $10 \mathrm{~d}$ in seawater containing $0.15 \mathrm{mg} \mathrm{l^{-1 }}$ of OA (A) or of OTC (C), or $1.50 \mathrm{mg} \mathrm{l}^{-1}$ of OA (B) or of OTC (D). Arrows indicate the end of the contamination period 
Table 1. Mean concentrations of oxolinic acid (OA) and oxytetracycline (OTC) in seawater, oyster and mussel tissues kept for $10 \mathrm{~d}$

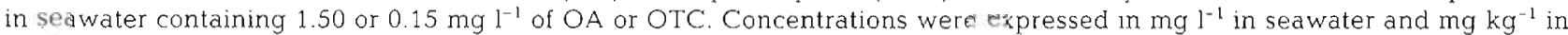
bivalve tissues. nd: not detected (concentration below the detection limits of the analyticai methods, i.e. $0.01 \mathrm{mg} \mathrm{l}^{-1}$ or mg $\mathrm{kg}^{-1}$ ); t: not determined

\begin{tabular}{|c|c|c|c|c|c|c|c|c|c|c|c|c|c|c|c|}
\hline & 0 & 1 & 2 & 4 & 5 & 6 & 7 & ${ }_{8}(\mathrm{~d}$ & 10 & 12 & 14 & 17 & 21 & 25 & 31 \\
\hline \multicolumn{16}{|c|}{$\mathrm{OA}\left(1.50 \mathrm{mg} \mathrm{l}^{-1}\right)$} \\
\hline Seawater & nd & 0.56 & 1.30 & 1.29 & 1.22 & 0.65 & 1.02 & 0.78 & 1.10 & nd & nd & nd & nd & nd & nd \\
\hline Oyster & nd & 3.30 & 1.81 & $\dagger$ & 2.30 & + & 1.14 & $\dagger$ & 1.42 & 0.14 & nd & nd & nd & nd & nd \\
\hline Mussel & nd & 2.92 & 1.87 & $\doteqdot$ & 6.32 & $\dagger$ & 2.43 & $\div$ & 1.07 & 0.06 & 0.01 & nd. & nd & nd & nd \\
\hline \multicolumn{16}{|c|}{$\mathrm{OA}\left(0.15 \mathrm{mg} \mathrm{l}^{-1}\right)$} \\
\hline Seawater & nd & 0.11 & 0.11 & 0.12 & 0.11 & 0.10 & 0.08 & 0.06 & 0.09 & nd & nd & nd & nd & nd & nd \\
\hline Oyster & nd & 0.22 & 0.21 & $\div$ & 0.19 & + & 0.13 & + & 0.09 & nd & nd & nd & nd & nd & nd \\
\hline Mussel & nd & 0.17 & 0.17 & + & 0.18 & + & 0.11 & + & 0.10 & nd & nd & nd & nd & nd & nd \\
\hline \multicolumn{16}{|c|}{ OTC $\left(1.50 \mathrm{mg} \mathrm{l}^{-1}\right)$} \\
\hline Seawater & nd & 1.22 & 0.93 & 1.29 & 0.92 & 0.99 & 0.93 & 0.57 & 1.14 & nd & nd & nd & nd & nd & nd \\
\hline Oyster & nd & 0.45 & 0.47 & + & 0.61 & 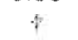 & 0.79 & + & 0.73 & 0.38 & 0.43 & 0.30 & 0.20 & 0.17 & 0.12 \\
\hline Mussel & nd & 0.58 & 0.72 & $\dagger$ & 1.02 & $\dagger$ & 1.25 & $\dagger$ & 1.01 & 0.50 & 0.43 & 0.23 & 0.13 & 0.09 & 0.05 \\
\hline \multicolumn{16}{|c|}{ OTC $\left(0.15 \mathrm{mg} \mathrm{l}^{-1}\right)$} \\
\hline Seawater & nd & 0.11 & 0.10 & 0.12 & 0.10 & 0.10 & 0.08 & 0.06 & 0.06 & nd & nd & nd & nd & nd & nd \\
\hline Oyster & nd & 0.05 & 0.06 & + & 0.08 & + & 0.09 & + & 0.11 & 0.06 & 0.04 & 0.04 & 0.03 & 0.01 & nd \\
\hline Mussel & nd & 0.06 & 0.07 & $t$ & 0.11 & + & 0.14 & + & 0.16 & 0.05 & 0.05 & 0.03 & 0.01 & nd & nd \\
\hline
\end{tabular}

OA and OTC concentrations in bivalve tissues respectively decreased and increased, apparently following changes in concentrations in seawater, between Day 2 and Day 10 of the experiment (Fig. 2, Table 1). In bivalve tissues, the mean OTC concentration was significantly lower than the mean OA concentration at a similar exposure $(p<0.05)$. OA concentrations in bivalve tissues, but not OTC concentrations, exceeded antibacterial agent concentrations in seawater (Fig. 2, Table 1).

Mean $\mathrm{OA}$ concentrations were not significantly different between oyster and mussel tissues at a similar exposure $(p>0.05)$. Mean OTC concentrations were significantly higher in mussel than in oyster tissues at a similar exposure $(p<0.05)$.

\section{Decontamination period}

OA concentrations in bivalve tissues rapidly declined below the detection limits from the 2 nd or the 4 th day after the end of the contamination. OTC concentrations in bivalve tissues decreased more slowly. OTC was detected at least until the 7 th day of the decontamination period (Fig. 2, Table 1).

Mean OTC concentrations were not significantly different in oyster and mussel tissues at a similar exposure $(p>0.05)$. In bivalve tissues, the mean OTC concentration was significantly different from the mean OA concentration at a similar exposure (Table 1). Parameters of the elimination kinetics of OTC in bivalve tissues were calculated (Table 2)
Elimination half-lives of OTC were $10 \mathrm{~d}$ in oysters and 5 to $7 \mathrm{~d}$ in mussels.

\section{DISCUSSION}

\section{Contamination period}

OTC/OA. At the same seawater concentrations, the OA concentrations in both bivalve tissues were higher than the OTC concentrations. This result could be explained by a difference in the accumulation of the free and bound forms of the antibacterial agents. In seawater, the OTC free forms are fewer than the OA free forms, because $95 \%$ of the OTC is bound to the calcium and magnesium ions in seawater (Lunestad \& Goksøyr 1990). Furthermore, OTC could be bound to

Table 2. Parameters of the elimination kinetics of oxytetracycline from oyster and mussel tissues (mono-compartmental model). $A$ and $k$ are coefficients of the equation $C=A \exp (-k t)$ describing the time course of oxytetracycline concentration in bivalve tissues $(C)$ in terms of the tume $(t) . t_{1 / 2}$ : half-life; MRT: mean residence time

\begin{tabular}{|ccccc|}
\hline & $A$ & $k$ & $t_{1 / 2}(\mathrm{~d})$ & MRT (d) \\
\hline Oyster & & & & \\
$1.50 \mathrm{mg} \mathrm{l}^{-1}$ & 0.455 & 0.069 & 10.11 & 14.58 \\
$0.15 \mathrm{mg} \mathrm{l}^{-1}$ & 0.061 & 0.068 & 10.18 & 14.69 \\
Mussel & & & & \\
$1.50 \mathrm{mg} \mathrm{l}^{-1}$ & 0.618 & 0.133 & 5.22 & 7.54 \\
$0.15 \mathrm{mg} \mathrm{l}^{-1}$ & 0.057 & 0.102 & 6.77 & 9.77 \\
\hline
\end{tabular}


organic molecules (Sithole \& Guy 1987). It was therefore possible that some of the OTC bound forms could not be absorbed by the bivalves. It is also possible that OTC biotransformation could be greater than OA biotransformation. However, in fish, OTC metabolism is lower than OA metabolism (Ueno et al. 1988a, b. Ishida 1990). Moreover, for other organic chemicals, bivalves have a lower metabolism rate than fish (Viarengo \& Canesi 1991, Kleinow et al. 1992, Livingston 1994). In addition, no metabolites of OTC or OA in the form of extra peaks on HPLC chromatograms could be seen in mussel or oyster tissues.

Oyster/mussel. OTC concentrations in mussel tissues were always higher than those in oyster tissues. These results could be related to the filtration rates of oyster and mussel. At the seawater temperature of the experiment, the filtration rate of the mussel is higher than that of the oyster (Walne 1972, Desious-Paoli et al. 1987, Vismann 1990).

Chemical dissociation or enzymatic degradation of complexes between OTC and cations or organic molecules could also be higher in the gut of the mussel than of the oyster. So, in the mussel, free forms of OTC could be liberated by this dissociation or degradation and therefore be absorbed easily. The anatomical and physiological characteristics of the mussel digestive tract differs from oyster, for example in the presence of bucco-œsophageal glands (Beninger et al. 1991). OTC biotransformation could also be higher in oyster than in mussel. In bivalves, xenobiotic metabolism is dependent on biological factors, such as species, age, sex and hormonal status, and environmental factors, such as presence or absence of chemical pollutants (Krieger et al. 1981, Livingston 1994).

These hypothetical explanations formulated for OTC are not supported for $O A$, since $O A$ concentrations in mussels and oysters were the same. Therefore, this phenomenon remained unclear.

\section{Decontamination period}

OTC/OA. The decontamination of oyster and mussel tissues by OA was faster than by OTC. Moreover, the OTC concentration to which bivalves were exposed during the contamination period had an influence on their tissues concentrations during the decontamination. Firstly, this may be explained by the fact that the binding of OTC to cations and proteins in tissues could be higher and/or more numerous than the binding of OA (Kellaway \& Marriott 1978, Björklund \& Bylund 1991). Indeed, the protein content of bivalve tissues represents 50 to $75 \%$ of their total organic matter (Deslous-Paoli \& Héral 1988). Secondly, OA biotransformation could be higher than OTC biotransforma- tion. This would be contradictory to observations from the contamination period. Differential metabolism of OTC and OA does not consistently explain both contamination and decontamination periods.

Oyster/mussel. The half-lives and mean residence times of OTC in oyster and mussel tissues were constant and concentration-independent. The elimination kinetics of OTC in bivalve tissues was therefore linear. Moreover, OTC elimination in mussel tissues was faster than in oyster tissues. This result could be related to the lower filtration rate of the oyster at the seawater temperature of the experiment. It could also be explained by a difference in the OTC metabolism in oyster and mussel, but that is inconsistent with the hypothesis formulated for the contamination period.

\section{Conclusion}

These results demonstrate the contamination of oyster and mussel when placed in seawater containing OTC or OA. OTC, which is in a large part bound to ions and organic molecules in seawater was less absorbed by bivalves than $O A$ and therefore contaminated their tissues less than did OA. OTC, whose binding to mineral and organic compounds of the bivalve tissues is stronger than $O A$, was more slowly eliminated from the bivalve tissues than $O A$. Therefore, differences in antibacterial agent contamination and decontamination of the bivalve tissues may be related to certain chemical properties of the antibacterial agent and to certain anatomical and physiological characteristics of the bivalve species. Antibacterial agent biotransformation by the bivalves did not seem to play a prominent part in contamination and decontamination of the bivalve tissues by OTC and OA, but further studies must be conducted to confirm this assumption.

Acknowledgements. We thank Ms. Michaëlle Larhantec and the technical staff of the IFREMER Laboratory for their helpful assistance.

\section{LITERATURE CITED}

Beninger PG, Le Pennec M, Donval A (1991) Mode of particle ingestion in five species of suspension-feeding bivalve molluscs. Mar Biol 108:255-261

Björklund HV, Bylund G (1991) Comparative pharmacokinetics and bioavailability of oxolinic acid and oxytetracycline in rainbow trout (Oncorhynchus mykiss). Xenobiotica 21. $1511-1520$

Cravedi JP, Choubert G, Delous G (1987) Digestibility of chloramphenicol, oxolinic acid and oxytetracycline in rainbow trout and influence of these antibacterial agents on lipid digestibility. Aquaculture 60:133-141

Deslous-Paoli JM, Héral M (1988) Biochemical composition and energy value of Crassostrea gigas (Thunberg) cul- 
tured in the bay of Marennes-Oléron. Aquat Living Res 1 $239-249$

Deslous-Paoli JM, Héral M, Goulletquer P, Boromtharanat W. Razet D, Garnier J, Prou J, Barillet L (1987) Evolution saisonnière de la filtration de bivalves intertidaux dans des conditions naturelles. Oceanis 13:575-579

Ervik A, Thorsen B, Eriksen V, Lunestad BT, Samuelsen OB (1994) Impact of administering antibacterial agents on wild fish and blue mussels Mytilus edulis in the vicinity of fish farms. Dis Aquat Org 18:45-51

Hansen KP, Lunestad BT, Samuelsen OB (1992) Ecological effects of antibiotics and chemotherapeutants from fish farming. In: Alderman DJ, Michel C (eds) Chemotherapy in aquaculture: from theory to reality. Office International des Epizooties, Paris, p 174-178

Ishida N (1990) Comparison of biliary metabolites of oxolinic acid in seven species of teleosts. Nippon Suisan Gakk 56: $55-59$

Kellaway IW, Marriott C (1978) The influence of drug hydrophobicity on the binding of tetracyclines to albumin. Can J Pharm Sci 13:90-93

Kleinow KM, James MO, Lech JJ (1992) Drug pharmacokinetics and metabolism in food-producing fish and crustaceans. In: Hutson DH, Hawkins DR, Paulson GD, Struble $\mathrm{CB}$ (eds) Xenobiotics and food-producing animals. American Chemical Society, Washington, p 98-130

Krieger RI, Gee SJ, Lim LO (1981) Marine bivalves, particulárly mussels, Mytilus $\mathrm{sp}$. for assessinent of envir onnenlal quality. Ecotoxicol Environ Saf 5:72-86

Le Bris $\mathrm{H}$, Pouliquen $\mathrm{H}$, Debernardi JM, Buchet V, Pinault L (1995) Preliminary study on the kinetics of oxytetracycline in shellfish exposed to an effluent of a land-based fish farm: experimental approach. Mar Environ Res 40: $171-180$

Livingston DR (1994) Recent developments in marine invertebrate organic xenobiotic metabolism. Toxicol Ecotox News 1:88-95

Lunestad BT (1992) Fate and effects of antibacterial agents in aquatic environments. In: Alderman DJ, Michel C (eds) Chemotherapy in aquaculture: from theory to reality. Office International des Epizooties, Paris, p 152-161.

Lunestad BT, Goksøyr J (1990) Reduction in the antibacterial effect of oxytetracycline in sea water by complex formation with magnesium and calcium. Dis Aquat Org 9:67-72

Peterson SM, Batley GE, Scammell MS (1993) Tetracycline in

This article was submitted to the editor antifouling paints. Mar Pollut Bull 26:96-100

Poulıquen H, Keita D, Pinault L (1992) Determination of oxytetracycline in marine shellfish (Crassostrea gigas, Ruditapes philippinarum and Scrobicularla plana) by high-performance liquid chromatography using solid phase extraction. J Chromatogr 627:287-293

Pouliquen H, Le Bris H, Pinault L (1993) Experimental study of the decontamination kinetics of seawater polluted by oxytetracycline contained in effluents released from a fish-farm located in a salt-marsh. Aquaculture 112 $113-123$

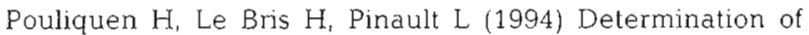
oxolınic acid in seawater, marine sediment and Japanese oyster (Crassostrea gigas) by high-performance liquid chromatography. J Liq Chromatogr 17:929-945

Samuelsen OB, Lunestad BT, Husevag B, Holleland T, Ervik A (1992) Residues of oxolinic acid in wild fauna following medication in fish farms. Dis Aquat Org 12:111-119

Samuelsen OB, Lunestad BT. Thorsen B, Eriksen V, Ervik A, Solheim $E$ (1993) Residues and effects of oxolinic acid in wild fauna following medication in fish farms. In: Haagsma N, Ruiter A, Czedik-Eysenberg PB (eds) Conference on residues of vetermary drugs in food. Faculty of Veterinary Medecine, Utrecht, p 606-610

Sithole BB, Guy RD (1987) Models for tetracycline in aquatic environments-II. Interaction with humic substances Water Air Soil Pollut 32:315-321

Tióbs JF, Eiston RA, Dickey RW, Guarnno AM (1989) Studies on the accumulation of antibiotics in shollfish. Northwest Environ J 5:161-162

Ueno R, Horiguchi Y, Kubota SS (1988a) Levels of oxolinic acid in cultured yellowtail after oral administration Nippon Suisan Gakk 54:479-484

Ueno R, Okumura M, Horiguchi Y, Kubota SS (1988b) Levels of oxolinic acid in cultured rainbow trout and amaggo salmon after oral administration. Nippon Suisan Gakk 54 $485-489$

Viarengo A, Canesi L (1991) Mussels as biological indicators of pollution. Aquaculture $94: 225-243$

Vismann B (1990) Field measurements of filtration and respiration rates in Mytilus edulis L. An assessment of methods. Sarsia 75:213-216

WaIne PR (1972) The influence of current speed, body size and water temperature on the filtration rate of five species of bivalves. J Mar Biol Ass UK 52:345-374

Manuscript first received: May 15, 1995

Revised version accepted: October 20,1995 